\title{
PENGEMBANGAN LKA DENGAN LATAR CERITA BERGAMBAR UNTUK MEMFASILITASI KETERAMPILAN SAINTIFIK AUD
}

\author{
Iis Haerunisa ${ }^{1}$, Edi Hendri Mulyana ${ }^{2}$, Sumardi ${ }^{3}$, Istikhoroh Nurzaman ${ }^{4}$ \\ Fakultas Keguruan dan Ilmu Pendidikan, Universitas Pendidikan Indonesia ${ }^{1234}$ \\ iishaerunisa22@upi.edu1, edihm@upi.edu², sumardi@upi.edu ${ }^{3}$, isti@upi.edu 4. \\ Haerunisa, Iis. Edi Hendri Mulyana, Sumardi, Istikhoroh Nurzaman. (2021). Pengembangan LKA dengan \\ Latar Cerita Bergambar untuk Memfasilitasi Keterampilan Saintifik AUD. Jurnal Pelita PAUD, \\ $6(1), 24-32$ \\ doi: https://doi.org/10.33222/pelitapaud.v6i1.1354
}

Diterima:20-06-2021

Disetujui: 07-08-2021

Dipublikasikan: 23-12-2021

Abstrak: Studi lapangan membuktikan jarang sekali terdapat konten pembelajaran sains pada LKA yang dijual oleh penerbit. Dasar selanjutnya karena cerita bergambar dapat dijadikan bentuk penyampaian materi pembelajaran kepada anak, apalagi dalam pembelajaran sains. Penelitian ini bertujuan untuk mengembangkan produk LKA dengan latar cerita bergambar untuk memfasilitasi keterampilan saintifik AUD. Metode yang digunakan adalah EDR model McKenney\& Reeves. Dengan 3 tahap, yaitu melakukan identifikasi dan analisis kebutuhan, rancangan produk, dan kelayakan produk. Berdasarkan hasil uji validitas produk diperoleh rata-rata 90,2\% dengan kategori sangat layak. Hasil uji kepraktisan guru $84 \%$ sangat praktis, kepraktisan anak $96 \%$ sangat praktis. Dan uji efektifitas $96 \%$ sangat efektif untuk memfasilitasi keterampilan saintifik AUD. Berdasarkan hasil tersebut, disimpulkan bahwa pengembangan LKA dengan latar Cerita Bergambar sangat layak, praktis dan efektif untuk memfasilitasi keterampilan saintifik AUD.

Kata kunci: Pengembangan, Lembar Kerja Anak, Cerita Bergambar Sains, Keterampilan Saintifik

Abstract: Field studies prove that there is rarely science learning content on LKA sold by publishers. The next basis is because picture stories can be used as a form of delivering learning material to children, especially in science learning. This study aims to develop LKA products with illustrated story backgrounds to facilitate AUD's scientific skills. The method used is the McKenney\& Reeves EDR model. With 3 stages, identifying and analyzing needs, product design, and product feasibility. Based on the results of the product validity test, an average of $90.2 \%$ was obtained with a very feasible category. The results of the practicality test of teachers are $84 \%$ very practical, $96 \%$ practicality of children is very practical. And the $96 \%$ effectiveness test is very effective in facilitating AUD scientific skills. Based on these results, it is concluded that the development of LKA with a picture story as the background is very feasible, practical and effective to facilitate AUD's scientific skills.

Keywords: Development, Worksheets, Science story book, Scientific Skills.

(C) 2021 Iis Haerunisa, Edi Hendri Mulyana, Sumardi, Istikhoroh Nurzaman. Under the license CC BY-SA 4.0

http://jurnal.upmk.ac.id/index.php/pelitapaud 


\section{PENDAHULUAN}

Pendekatan saintifik (pendekatan ilmiah) adalah salah satu pendekatan dalam membangun cara berpikir agar anak dapat secara aktif membangun konsep melalui proses mengamati, menanya, mengumpulkan informasi, menalar dan mengkomunikasikan. Pendekatan saintifik juga dapat menstimulus perkembangan anak baik bahasa, motoric, kognitif, seni, agama, maupun social emosionalnya (Hafidz et al., 2018). Hal ini pun menjadi tuntutan Kurikulum 2013 PAUD (Permendikbud No 146 Tahun 2014, 2014, p. 2) yang mewajibkan seluruh pembelajaran menggunakan pendekatan saintifik (Nugraha et al., 2015, p. 2), termasuk pada pembelajaran sains.

Membuat anak berperan aktif dalam pembelajaran sains merupakan hal yang harus diperhatikan oleh pelaku pendidikan. Pada dasarnya pembelajaran sains di PAUD masih belum optimal karena aktivitas pembelajaran yang masih terpusat pada guru, konsep sains yang disampaikan masih bersifat abstrak dan sulit di pahami (Susdarwati \& Agustina, 2018, p. 152). Iklim yang menarik dan membuat anak semangat merupakan kunci utama dalam pembelajaran. Pembelajaran sains hendaknya menekankan pada aktivitas belajar, bukan produk (Juniarti, 2017, p. 75) aktivitas belajar ini hendaknya didukung dengan media atau bahan ajar yang dapat mendukung keterampilan saintifik anak. Lembar Kerja Anak merupakan salah satu sumber bahan ajar yang dapat dikembangkan langsung oleh guru, sehingga dapat dibuat lebih menarik serta lebih kontekstual dengan keadaan sekolah dan karakteristik siswa.

Lembar kegiatan anak (student worksheet) merupakan lembaran-lembaran berisi tugas yang menekankan pada pemahaman konsep (Depdiknas, 2008, p. 13). Lembar kegiatan ini biasanya berupa petunjuk, langkah-langkah untuk menyelesaikan suatu tugas. Pendekatan saintifik dapat diintegrasikan dengan LKA yang dapat dikembangkan sendiri, dengan begitu akan terjadi interaksi anak dan guru sebagai fasilitator (Rahayuningsih et al., 2019, p. 2).

Studi pendahuluan yang dilakukan pada 18-30 Desember 2020 di tiga satuan PAUD (RA Nurul Firdaus, TK Mekar Tanjung dan TKIP Assalam) yang berada di Panumbangan dengan jumlah responden 5 guru yang diwawancarai. Berdasarkan data yang diperoleh menunjukkan bahwa LKA sangat diperlukan dalam proses pembelajaran, namun untuk LKA berbasis sains guru jarang bahkan hamper tidak pernah menggunaan LKA, karena tidak ada dalam Majalah (LKA yang disediakan percetakan). Untuk pembelajaran sains akan suka diikutsertakan dalam percobaannya saja, jarang menggunakan LKA. Hal ini menggambarkan peran LKA dalam proses pembelajaran belum cukup optimal. Hal isi sejalan dengan penelitian yang dilakukan oleh Resa Pujiaswati (Pujiaswati et al., 2020, p. 108) bahwa banyak LKA yang masih tidak sesuai dengan tujuan pembelajaran. LKA yang digunakan belum mendukung untuk pembelajaran siswa yang aktif dan mandiri. Selain itu banyak ditemukan LKA yang tidak sesuai dengan aspek pengembangan terutama untuk memfasilitasi keterampilan proses saintifik.

Dalam penggunaan LKA model sains (Pujiaswati et al., 2020, p. 89) harus dipastikan bahwa anak mengetahui materi yang akan dipelajarinya terlebih dahulu, karena pembelajaran sains, teknologi, enginerring dan matematika bersifat aplikatif. Maka (Prastowo, A. 2016, hlm. 204) tugas-tugas sebuah lembar kegiatan tidak akan dapat dikerjakan oleh peserta didik secara baik apabila tidak dilengkapi dengan buku atau referensi lain yang terkait dengan materi tugasnya.

Banyak cara untuk menerapkan pembelajaran sains pada anak usia dini Berdasarkan prinsip pembelajaran anak usia dini, (Abidin, 2013, p. 2) pembelajaran anak usia dini dapat dilakukan dalam tiga cara yakni bermain, bercerita, dan berbuat. Bercerita adalah salah satu pendekatan 
pembelajaran yang menarik bagi anak, sederhana dan mudah dipahami (Hariyanti, 2019 , p. 107) namun mulai banyak ditinggalkan. Isi sebuah cerita/dongeng pun tidak selalu hal yang bersifat imajinatif dan fiksional. Sebuah cerita juga dapat berisi muatan sains, matematis, kewarganegaraan, maupun ilmu pengetahuan yang lain (Abidin, 2013, p. 5)

Pengenalan konsep menggunakan lembar kerja anak dengan latar cerita bergambar merupakan suatu teknik pembelajaran baru yang dapat diterapkan di anak usia dini. Konsep Lembar Kerja dengan latar cerita bergambar ini, sejalan dengan beberapa hasil penelitian yang dilakukan oleh Nurhidayah (Nurhidayah \& Wangid, 2020), Pengembangan bahan ajar buku dongeng berbasis sainsmatika untuk meningkatkan pemahaman konsep, dengan hasil penelitiannya buku dongeng berbasis sainsmatika ini layak dan efektif untuk meningkatkan pemahaman konsep sainsmatika anak. Serta pada penelitian yang dilakukan Nurhidayah (Nurhidayah \& Wangid, 2020), terbukti bahwa dongeng dapat meningkatkan pemahaman konsep sainsmatika melalui dongeng berbasis sainsmatika. Hal yang sama dilakukan juga oleh dari Dores (Dores \& Setiawan, 2018), mengenai Pengembangan LKS berbasis dongeng untuk meningkatkan literasi matematis siswa sekolah dasar se-kota sintang, terbukti bahwa LKS berbasis dongeng dapat meningkatkan kemampuan literasi matematis siswa. Berdasarkan hasil studi pendahuluan wawancara bersama beberapa guru dari RA Nurul Firdaus, TK Mekar Tanjung, dan TK IP Assalam menunjukkan bahwa metode bercerita sebagai media penyampaian materi sangat bagus dan cocok sekali digunakan pada anak usia dini.

Hal ini dilakukan juga oleh Cahaya, I.M.E dan Poerwati (Cahaya \& Poerwati, 2017), pada penelitiannya dengan judul Efektivitas mendongeng dalam meningkatkan kemampuan matematika anak usia dini, hasil dari penelitian ini menunjukkan peningkatan kemampuan matematika anak melalui metode mendongeng, metode mendongeng sebagai salah satu alternatif metode pembelajaran yang kreatif, inovatif dan efektif dalam meningkatkan kemampuan matematika anak usia dini. Pengembangan tersebut disesuaikan dengan dasar kebutuhan pengembangannya.
Berdasarkan permasalahan dan fakta-fakta dilapangan serta penelitian yang relevan, pada penelitian ini akan dilakukan pengembangan LKA dengan latar cerita bergambar yang belum pernah diterapkan oleh sekolah. LKA dengan latar cerita bergambar ini diharapkan dapat memfasilitasi keterampilan saintifik pada konsep gerak benda.

\section{METODE PENELITIAN}

\section{Jenis Penelitian}

Penelitian ini menggunakan metode penelitian Education Design Reseach (EDR) model McKenney\& Reeves (Lidinillah, 2012, p. 14) . Model penelitian ini terdiri dari tiga langkah yaitu : 1) analisis dan eksplorasi; 2) desain dan kontruksi; 3) evaluasi dan refleksi

\section{Waktu dan Tempat Penelitian}

Waktu pelaksanaan penelitian ini yaitu 1830 Desember 2020 studi lapangan untuk menganalisis kebutuhan dasar pengembangan. Pada Mei-Juni 2021 mulai persiapan dan uji coba. Tempat penelitian dilaksanakan di RA Nurul Firdaus yang terletak di Kecamatan Panumbangan Kabupaten Ciamis. Pada tanggal 05 Juni 2021

\section{Subjek Penelitian}

Subjek pada saat studi pendahuluan yaitu guru PAUD kelompok B. Subjek expert judgement yaitu ahli materi, ahli media dan ahli bahasa. Terakhir subjek uji coba yaitu anak usia 5-6 tahun atau kelompok B, serta guru kelompok B di RA Nurul Firdaus Panumbangan.

\section{Data, Intrumen, dan Teknik Pengumpulan Data}

Jenis data yang dibutuhkan dalam penelitian ini disesuaikan dengan tahap penelitian, yaitu, analisis dan eksplorasi, pada tahap ini memerlukan data mengenai dasar kebutuhan pengembangan LKA cerita bergambar, serta contoh LKA yang ada dilapangan sebagai acuan untuk pengembangan LKA selanjutnya. Data ini didapatkan pada saat studi pendahuluan. Desain dan Kontruksi, pada tahap ini memerlukan data mengenai Proses Penyusunan Rancangan Pengembangan LKA cerita bergambar berupa masukan dari para ahli materi, media dan ahli bahasa. Evaluasi dan Refleksi, pada tahap ini memerlukan data mengenai hasil uji coba praktikalitas yang dilakukan oleh anak dan guru. Serta memerlukan data hasil uji coba efektivitas 
Pengembangan LKA dengan ....

lis Haerunisa', Edi Hendri Mulyana 2, Sumardi³, Istikhoroh Nurzaman ${ }^{4}$

P ISSN 2548-6284 E ISSN 2615-0360

Vol. 6 No. 1 Desember 2021

kegiatan pembelajaran kepada anak dalam memfasilitasi keterampilan saintifik AUD.

Data dikumpulkan melalui wawancara dengan instrumen lembar wawancara, validasi dari expert judgement menggunakan instrumen lembar validasi, angket uji praktikalitas, lembar observasi uji efektivitas, dan dokumentasi.

\section{Teknik Analisis Data}

Teknik analisis data melalui tiga tahap, pertama analisis hasil studi pendahuluan yang diolah menggunakan deskriptif kualitatif; kedua analisis hasil rancangan produk berdasarkan hasil penilaian ahli menggunakan statistik deskriptif dengan menghitung score rata-rata hasil validasi; ketiga uji kelayakan diperoleh dari respon guru dan anak, serta hasil belajar anak dalam menggunakan produk yang dikembangkan, hasil ini dianalisis menggunakan statistika deskriptif.

\section{HASIL PENELITIAN PEMBAHASAN}

\section{Analisis dan Eksplorasi}

Tahap ini dilakukan untuk mengetahui dasar kebutuhan dari pengembangan LKA dengan latar cerita bergambar. Berdasarkan hasil pengumpulan data yang dilakukan di RA Nurul Firdaus dan TK Mekar Tanjung Panumbangan, Kab. Ciamis. Berdasarkan data membuktikan bahwa LKA sangat dibutuhkan dalam proses pembelajaran guru dan siswa. Namun untuk pembelajaran sains di PAUD jarang sekali menggunakan LKA. Hal ini karena para guru terlalu mengandalkan LKA yang dibeli dari percetakan penerbit tertentu. Selain itu terdapat banyak LKA yang menekankan pada evaluasi kognitif dan kegiatan seni tanpa membantu menemukan suatu konsep. Hal ini juga yang menjadikan keterampilan saintifik yang menjadi tuntutan kurikulum tidak terstimulus secara optimal.

Berdasarkan hal tersebut membuktikan adanya kesenjangan antara fungsi LKA dengan implikasi dilapangan. Lembar kerja anak merupakan lembar kerja yang harus diisi oleh anak serta berisi petunjuk atau langkahlangkah untuk menyelesaikan tugas (Depdiknas, 2008, p. 13). LKA juga berperan untuk membantu anak dalam menemukan konsep, serta agar anak aktif dan mandiri dalam pemebelajarannya. Selain itu Menurut Prastowo (Amali et al., 2019, p. 193) bahan ajar LKA tersusun dari enam unsur yaitu judul, petunjuk belajar, kd atau materi, informasi pendukung, tugas atau langkah kerja dan penilaian.

Syarat penyusunan LKA menurut Hendro Darmodjo \& Jenny R.E (dalam Pertiwi, 2017, hlm. 13) ada tiga yaitu didaktik yang bersifat universal serta menekankan pada proses untuk menemukan konsep; konstruksi yang berhubungan dengan penggunaan bahasa; serta teknis yang berhubungan dengan penyajian.

Hal yang sama terjadi pada kegiatan bercerita di dalam kelas. Berdasarkan data yang didapat kegiatan bercerita didalam kelas sering dilakukan pada kegiatan awal sebelum masuk ke kegiatan inti, seperti pada kegiatan apersepsi dan pada kegiatan awal yang dijadikan agar anak mau mengikuti pembelajaran. Hal ini sejalan menurut Hartati karena dengan bercerita dapat mempermudah pemahaman konsep yang rumit menjadi lebih sederhana dan lebih menyenangkan (Hartati, A \& dkk, 2018, hlm. 3). Isi dalam cerita pun tidak selalu yang bersifat imajinatif dan fiksional. Sebuah cerita/dongeng juga dapat berisi muatan sains, matematis, kewarganegaraan, maupun ilmu pengetahuan yang lain (Abidin, Y. 2013, hlm. 5).

Namun berdasarkan fakta yang ditemukan, kegiatan bercerita bermuatan sains belum pernah dilakukan. Hal ini karena terbatasnya buku cerita apalagi buku cerita bermuatan sains. Berdasarkan hal tersebut, dapat diidentifikasi bahwa guru mengetahui manfaat dari kegiatan bercerita, namun memang terkendala dalam keterbatasan buku cerita.

Cerita bergambar pada umumnya terdiri dari 32 halaman (Ratnasari \& Zubaidah, 2019, p. 269) serta harus memiliki unsur pembangun (Musfiroh, 2005, hlm. 38) seperti tokoh, amanat, tema, alur, setting, sudut pandang serta sarana kebahasaan.

Untuk menciptakan pembelajaran yang bermakna dan memfasilitasi keterampilan saintifik anak, diperlukannya suatu terobosan baru agar anak berperan aktif dalam melakukan pengamatan, percobaan dan menciptakan suatu produk. LKA dengan latar cerita bergambar dengan konsep gerak benda menjadi solusi 
untuk memfasilitasi keterampilan saintifik anak usia dini serta sebagai contoh terhadap realisasi tuntutan dari kurikulum 2013.

\section{Desain dan Kontruksi}

\section{Rancangan Pengembangan}

Tahap ini dilakukan untuk mengetahui rancangan pengembangan dari pengembangan LKA dengan latar cerita bergambar. LKA dengan latar cerita bergambar ini disusun berdasarkan kebutuhan terhadap bahan ajar guru dan siswa untuk mendukung pembelajaran di kelompok B PAUD pada tema Alam Semesta sub tema Udara, dengan konsep yang dikenalkan adalah konsep gerak benda : aksi-reaksi pada pembelajaran sains untuk anak usia dini.

Sebelum merancang produk, peneliti melakukan analis kurikulum untuk menentukan materi, KD dan capaian yang akan di kembangkan dalam produk. Selanjutnya membuat prototype kemudian divalidasi oleh validator ahli sampai produk dinyatakan valid dan siap di ujicobakan.

Pembuatan LKA dengan latar cerita bergambar ini dilakukan dengan dua cara, LKA pada aplikasi Corel Draw x7, sedangan cerita bergambar dilakukan sketsa manual, kemudian di scan dan di gambar secara digital menggunakan aplikasi Medibang dan Corel Draw x 7 .

Berikut beberapa desain LKA dengan latar cerita bergambar, dapat dilihat pada Gambar 1 .
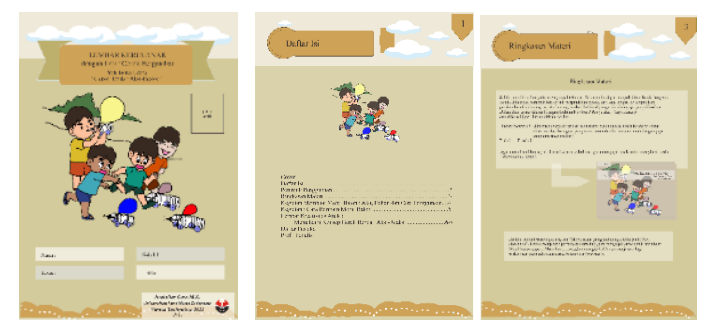

Gambar 1. Desain LKA

(cover, daftar isi, ringkasan materi)

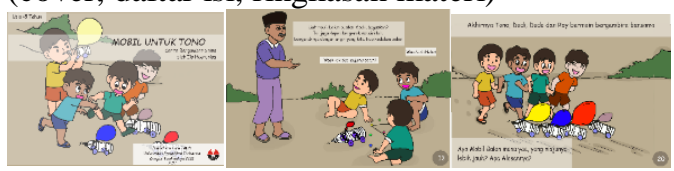

Gambar 2. Desain cerita bergambar (cover, bagian cerita, akhir cerita yang terdapat pertanyaan pretest)

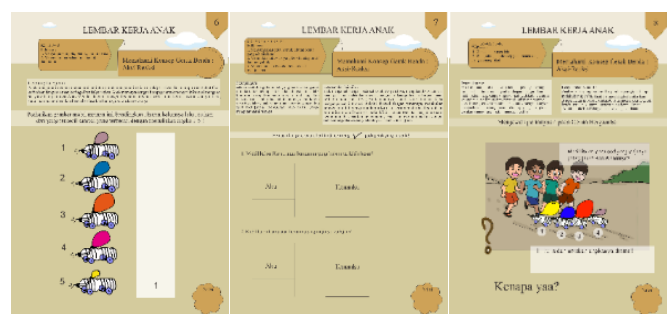

Gambar 3. Lembar kegiatan anak

Uji validasi produk melibatkan tiga ahli yaitu ahli materi sains, ahli bahasa dan ahli media. Uji validasi produk oleh ahli materi dilakukan 2x dengan hasil uji produk ke-1 76,6\% dan ke$284,6 \%$ hal ini terdapat kenaikan nilai sebesar $8 \%$. Berikut hasil validasi oleh ahli materi:

Tabel 1. Hasil uji produk oleh ahli materi

\begin{tabular}{|c|c|c|c|}
\hline No. & $\begin{array}{c}\text { Aspek } \\
\text { Penilaian }\end{array}$ & Persentase & Kategori \\
\hline 1 & $\begin{array}{l}\text { Kesesuaian } \\
\text { materi }\end{array}$ & $91 \%$ & $\begin{array}{l}\text { Sangat } \\
\text { Layak }\end{array}$ \\
\hline 2 & $\begin{array}{l}\text { Keakuratan } \\
\text { materi }\end{array}$ & $91 \%$ & $\begin{array}{l}\text { Sangat } \\
\text { Layak }\end{array}$ \\
\hline 3 & $\begin{array}{l}\text { Mendorong } \\
\text { keingintahuan }\end{array}$ & $75 \%$ & Layak \\
\hline 4 & $\begin{array}{l}\text { Teknik } \\
\text { Penyajian }\end{array}$ & $83 \%$ & $\begin{array}{l}\text { Sangat } \\
\text { Layak }\end{array}$ \\
\hline 5 & $\begin{array}{l}\text { Hakikat } \\
\text { Kontekstual }\end{array}$ & $83 \%$ & $\begin{array}{l}\text { Sangat } \\
\text { Layak }\end{array}$ \\
\hline Mean & & $84,6 \%$ & gat Layak \\
\hline
\end{tabular}

Uji validasi oleh ahli media dilakukan $2 \mathrm{x}$ dengan hasil uji produk ke-1 $79 \%$ dan ke-2 95\% hal ini terdapat kenaikan nilai sebesar $16 \%$. Berikut hasil validasi oleh ahli media:

Tabel 2. Hasil uji produk oleh ahli media

\begin{tabular}{|c|c|c|c|}
\hline No. & $\begin{array}{c}\text { Aspek } \\
\text { Penilaian }\end{array}$ & Persentase & Kategori \\
\hline 1 & Komponen & $100 \%$ & $\begin{array}{l}\text { Sangat } \\
\text { Layak }\end{array}$ \\
\hline 2 & Daya Tarik & $93 \%$ & $\begin{array}{l}\text { Sangat } \\
\text { Layak }\end{array}$ \\
\hline 3 & $\begin{array}{l}\text { Penampilan } \\
\text { dan struktur }\end{array}$ & $93 \%$ & $\begin{array}{l}\text { Sangat } \\
\text { Layak }\end{array}$ \\
\hline Mean & & $95 \%$ & gat Layak \\
\hline
\end{tabular}

Uji validasi oleh ahli bahasa dilakukan $2 \mathrm{x}$ dengan hasil uji produk ke-1 74,5\% dan ke-2 $91,25 \%$ hal ini terdapat kenaikan nilai sebesar $16,75 \%$. Berikut hasil validasi oleh ahli bahasa: 
P ISSN 2548-6284 E ISSN 2615-0360

Vol. 6 No. 1 Desember 2021

Tabel 3. Hasil uji produk oleh ahli bahasa

\begin{tabular}{llcl}
\hline No. & \multicolumn{1}{c}{$\begin{array}{c}\text { Aspek } \\
\text { Penilaian }\end{array}$} & Persentase & Kategori \\
\hline 1 & $\begin{array}{l}\text { Kemudahan } \\
\text { Penggunaan }\end{array}$ & $89 \%$ & $\begin{array}{l}\text { Sangat } \\
\text { Praktis }\end{array}$ \\
2 & $\begin{array}{l}\text { Kemenarikan } \\
\text { Sajian }\end{array}$ & $87 \%$ & $\begin{array}{l}\text { Sangat } \\
\text { Bahasa }\end{array}$ \\
& Bahaktis \\
& & $76 \%$ & $\begin{array}{l}\text { Sangat } \\
\text { Praktis }\end{array}$ \\
\hline Mean & & $84 \%$ & \multicolumn{2}{c}{ Sangat Praktis } \\
\hline
\end{tabular}

Berdasarkan hasil uji validitas produk diperoleh rata-rata 90,2\% dengan kategori sangat layak. LKA terdiri dari cover, daftar isi, petunjuk untuk guru, ringkasan materi yang mengarah pada cerita bergambar, alat dan bahan serta petunjuk penggunaan, lembar kegiatan anak, dan profil penulis. Latar cerita bergambar dalam LKA ini dijadikan sebagai media penyampaian materi pembelajaran sains. Cerita bergambar terdiri dari cover, identitas pengarang, isi cerita, pre-test (yang dapat dijawab dengan mengerjakan LKA), dan profil penulis.

Pada pembelajaran menggunakan LKA dengan latar cerita bergambar ini memuat 4 Kompetensi Dasar yang mengacu pada kurikulum 2013. Kompetensi dasar tersebut memuat 2.2, 3.6-4.6, 3.8-4.8, dan 3.9-4.9. Dengan indikator pencapaian anak dapat mengetahui sebab-akibat mobil balon dapat bergerak, anak dapat mengetahui konsep gerak benda yang dipengaruhi oleh gaya, anak dapat melakukan proses kerja sesuai prosedur ilmiah, serta anak dapat membuat mobil balon sesuai dengan kreativitasnya. Indikator pencapaian tersebut disesuaikan dengan muatan yang tertulis pada LKA cerita bergambar serta pada proses pembelajaran di kelas.

Produk LKA terdiri dari 9 halaman, dengan cover, daftar isi, petunjuk penggunaan, ringkasan materi yang menunjukan pada cerita bergambar, alat dan bahan, cara membuat mobil balon, 3 halam sebagai aktivitas siswa, dan profil penulis. Sedangkan cerita bergambar berisi 21 halaman, dengan cover, isi cerita dan profil penulis. LKA di cetak dengan ukuran A4 sedangkan cerita bergambar ukuran B5.

Evaluasi dan Refleksi

Kelayakan Pengembangan
Berdasarkan uji produk terhadap guru dan siswa. Menunjukkan bahwa LKA dengan Latar Cerita Bergambar ini Sangat Layak digunakan sebagai bahan ajar di PAUD. Dengan hasil uji kepraktisan oleh guru $84 \%$, uji kepraktisan oleh anak 96\% (yang diisi oleh observer/penilai)

Berikut hasil uji kepraktisan bagi guru: Tabel 4. Hasil uji kepraktisan bagi guru

\begin{tabular}{|c|c|c|c|}
\hline No. & $\begin{array}{c}\text { Aspek } \\
\text { Penilaian }\end{array}$ & Persentase & Kategori \\
\hline 1 & $\begin{array}{l}\text { Kesesuaian } \\
\text { dengan tingkat } \\
\text { perkembangan } \\
\text { anak }\end{array}$ & $91 \%$ & $\begin{array}{l}\text { Sangat } \\
\text { Layak }\end{array}$ \\
\hline 2 & Komunikatif & $83 \%$ & $\begin{array}{l}\text { Sangat } \\
\text { Layak }\end{array}$ \\
\hline 3 & $\begin{array}{l}\text { Kesesuaian } \\
\text { dengan kaidah } \\
\text { kebahasaan }\end{array}$ & $91 \%$ & $\begin{array}{l}\text { Sangat } \\
\text { Layak }\end{array}$ \\
\hline 4 & $\begin{array}{l}\text { Dialogis dan } \\
\text { interaktif }\end{array}$ & $100 \%$ & $\begin{array}{l}\text { Sangat } \\
\text { Layak }\end{array}$ \\
\hline Mean & & $25 \%$ & gat Layak \\
\hline
\end{tabular}

Tabel 5. Hasil uji kepraktisan bagi anak

\begin{tabular}{lll}
\hline No & Indikator & Persentase \\
\hline 1 & $\begin{array}{l}\text { Kejelasan petunjuk } \\
\text { menggunakan LKA } \\
2\end{array}$ & $\begin{array}{l}\text { Memudahkan memahami } \\
\text { konsep gerak benda }\end{array}$ \\
3 & $\begin{array}{l}\text { LKA membangkitkan } \\
\text { motivasi dan aktivitas belajar } \\
\text { anak }\end{array}$ & $100 \%$ \\
4 & $\begin{array}{l}\text { LKA meningkatkan } \\
\text { kemandirian anak } \\
5\end{array}$ & $\begin{array}{l}\text { Desain LKA menarik } \\
\text { perhatian anak }\end{array}$ \\
\hline & Hasil & $100 \%$ \\
\hline
\end{tabular}

Hasil uji efektifitas terhadap hasil belajar 6 anak pada kelompok B RA Nurul Firdaus, 96\% capaian perkembangan anak adalah BSB (berkembang sangat baik). Hal ini membuktikan bahwa produk LKA dengan latar cerita bergambar sangat efektif untuk memfasilitasi keterampilan saintifik AUD. Tabel 6. Rekapitulasi Nilai Keterampilan Saintifik

\begin{tabular}{lllllll}
\hline \multirow{2}{*}{ Aspek } & \multicolumn{5}{c}{ Jumlah Siswa } \\
\cline { 2 - 7 } & A1 & A2 & A3 & A4 & A5 & A6 \\
\hline Mengamati & BSB & BSB & BSB & BSB & BSB & BSB \\
\hline Menanya & BSB & BSB & BSB & BSB & BSH & BSH \\
\hline $\begin{array}{l}\text { Mengumpulkan } \\
\text { Informasi }\end{array}$ & BSB & BSB & BSB & BSB & BSB & BSH \\
\hline
\end{tabular}




\begin{tabular}{|c|c|c|c|c|c|c|}
\hline Menalar & BSB & BSB & BSB & BSB & BSB & BSB \\
\hline $\begin{array}{l}\text { Mengkomunikasik } \\
\text { an }\end{array}$ & BSB & BSB & BSB & BSB & BSB & BSB \\
\hline Jumlah & $\begin{array}{l}100 \\
\%\end{array}$ & $\begin{array}{l}100 \\
\%\end{array}$ & $\begin{array}{l}100 \\
\%\end{array}$ & $\begin{array}{l}100 \\
\%\end{array}$ & $95 \%$ & $90 \%$ \\
\hline
\end{tabular}

Efektif)

Refleksi produk menghasilkan produk akhir yaitu pengembangan LKA dengan latar cerita bergambar untuk memfasilitasi keterampilan saintifik AUD. Produk ini berupa bahan ajar LKA dengan cerita bergambar yang dikemas dengan baik agar terlihat praktis, awet dan dapat dibawa kemana-mana.

Adapun kelebihan dan kekurangan dari LKA dengan latar cerita bergambar pada kelompok B, diantaranya (a) Kelebihan : dirancang sesuai dengan KD pada kurikulum 2013; dirancang berdasarkan tema pembelajaran di PAUD; dirancang untuk variasi pembelajaran sains; mudah digunakan; penyampaian konsep sains yang telah disederhanakan; menarik untuk pembelajaran; mempunyai nilai edukatif. (b) Kekurangan : guru harus belajar cara bercerita yang menyenangkan, hal ini agar pembelajaran tidak jenih; guru harus melakukan kegiatan ekstra seperti melubangi botol sesuai pola.

Latar cerita bergambar yang dimaksud adalah cerita bergambar yang dijadikan media penyampaian konsep sains yang lebih sederhana, agar anak belajar dengan menyenangkan serta memahami dengan mudah. Berdasarkan studi lapangan di RA Nurul Firdaus, TK Mekar Tanjung dan TK IP Assalam, guru masih banyak mengandalkan LKA yang dibeli dari penerbit untuk dijadikan kegiatan inti dan konten LKA yang disediakan jarang sekali yang melibatkan pembelajaran sains. Pada metode penyampaiannya pun kurang bervariatif, padahal dapat mengunakan metode bercerita sebagai jembatan memudahkan pemahaman konsep dengan cara yang lebih menyenangkan. Berdasarkan hal tersebut, maka perlu dilakukan pengembangan LKA dengan latar cerita bergambar untuk memfasilitasi keterampilan saintifik AUD

Rancangan LKA yang dibuat oleh peneliti yaitu pengembangan LKA dengan latar cerita bergambar untuk memfasilitasi keterampilan saintifik AUD. Tahap perancangan ini mengacu pada metode pengembangan EDR model McKenney\& Revees. Pada tahap ini dihasilkan rancangan LKA dengan latar cerita bergambar untuk memfasilitasi keterampilan saintifik AUD yang telah di validasi oleh ahli materi, media dan bahasa. Hasil validasi yang dilakukan 2x menunjukkan 90,2\% dengan latar cerita bergambar sangat layak digunakan sebagai bahan ajar di PAUD. Dengan rincian, ahli materi $84,6 \%$, ahli media $95 \%$, dan ahli bahasa $91,25 \%$.

Kelayakan pengembangan LKA dengan latar cerita bergambar ini berdasarkan hasil uji kepraktisan terhadap guru sebesar $84 \%$ sangat praktis, uji kepraktisan terhadap anak $96 \%$ sangat praktis. Terakhir berdasarkan uji efektifitas menunjukan 96\% menunjukkan anak dapat berkembang sangat baik, hal ini menujukan bahwa LKA dengan latar cerita bergambar sangat efektif untuk memfasilitasi keterampilan saintifik AUD.

LKA dengan latar cerita bergambar ini dirancang untuk menyampaikan pembelajaran sains kepada anak usia 5-6 tahun melalui percobaan, sehingga anak dapat mengisi LKA berdasarkan hasil percobaan yang dilakukannya. Serta sebagai solusi dari keterbatasan media bahan ajar pembelajaran sains.

LKA dengan latar cerita bergambar ini dapat memfasilitasi keterampilan saintifik sesuai amanat kurikulum 2013. LKA dengan latar cerita bergambar ini praktis, alat dan bahan yang digunakan dalam percobaannya pun berasal dari bahan bekas dan mudah didapat. LKA dengan latar cerita bergambar ini memberi pengalaman langsung dalam proses pembelajaran bagi anak. Konsep LKA dengan cerita bergambar ini dapat di modifikasi dengan tema/konten-konten pembelajaran lain yang relevan, untuk menciptakan pembelajaran yang bermakna dan memfasilitasi keterampilan saintifik anak, diperlukannya suatu terobosan baru agar anak berperan aktif dalam melakukan pengamatan, percobaan dan menciptakan suatu produk. LKA dengan latar cerita bergambar dengan konsep gerak benda menjadi solusi untuk memfasilitasi keterampilan saintifik anak usia dini serta sebagai contoh terhadap realisasi tuntutan dari kurikulum 2013.

\section{SIMPULAN}

Berdasarkan hasil penelitian, dapat disimpulkan bahwa pengembangan LKA dengan latar cerita bergambar ini sesuai dengan kebutuhan dasar berdasarkan studi lapangan dan studi literatur. Dasar kebutuhan rancangan 
Pengembangan LKA dengan ....

lis Haerunisa', Edi Hendri Mulyana 2, Sumardi3, Istikhoroh Nurzaman

P ISSN 2548-6284 E ISSN 2615-0360

Vol. 6 No. 1 Desember 2021

pengembangan LKA dengan latar cerita bergambar ini merujuk pada tuntutan teoritis dan kebutuhan dilapangan. Bentuk LKA pada umumnya digunakan sebagai alat evaluasi dari pembelajaran. Namun hakikatnya LKA dibuat untuk membantu anak dalam proses pembelajaran tidak hanya alat evaluasi saja. Latar cerita bergambar yang dimaksud adalah cerita bergambar yang dijadikan media penyampaian konsep sains yang lebih sederhana, agar anak belajar dengan menyenangkan serta memahami dengan mudah. Berdasarkan studi lapangan di RA Nurul Firdaus, TK Mekar Tanjung dan TK IP Assalam, guru masih banyak mengandalkan LKA yang dibeli dari penerbit untuk dijadikan kegiatan inti dan konten LKA yang disediakan jarang sekali yang melibatkan pembelajaran sains. Pada metode penyampaiannya pun kurang bervariatif, padahal dapat mengunakan metode bercerita sebagai jembatan memudahkan pemahaman konsep dengan cara yang lebih menyenangkan. Berdasarkan hal tersebut, maka perlu dilakukan pengembangan LKA dengan latar cerita bergambar untuk memfasilitasi keterampilan saintifik AUD

Rancangan LKA yang dibuat oleh peneliti yaitu pengembangan LKA dengan latar cerita bergambar untuk memfasilitasi keterampilan saintifik AUD. Tahap perancangan ini mengacu pada metode pengembangan EDR model McKenney\& Revees. Pada tahap ini dihasilkan rancangan LKA dengan latar cerita bergambar untuk memfasilitasi keterampilan saintifik AUD yang telah di validasi oleh ahli materi, media dan bahasa. Hasil validasi yang dilakukan 2x menunjukkan 90,2\% dengan latar cerita bergambar sangat layak digunakan sebagai bahan ajar di PAUD. Dengan rincian, ahli materi $84,6 \%$, ahli media $95 \%$, dan ahli bahasa $91,25 \%$.

Kelayakan pengembangan LKA dengan latar cerita bergambar ini berdasarkan hasil uji kepraktisan terhadap guru sebesar $84 \%$ sangat praktis, uji kepraktisan terhadap anak $96 \%$ sangat praktis. Terakhir berdasarkan uji efektifitas menunjukan $96 \%$ menunjukkan anak dapat berkembang sangat baik, hal ini menujukan bahwa LKA dengan latar cerita bergambar sangat efektif untuk memfasilitasi keterampilan saintifik AUD.

LKA dengan latar cerita bergambar ini dirancang untuk menyampaikan pembelajaran sains kepada anak usia 5-6 tahun melalui percobaan, sehingga anak dapat mengisi LKA berdasarkan hasil percobaan yang dilakukannya. Serta sebagai solusi dari keterbatasan media bahan ajar pembelajaran sains.

LKA dengan latar cerita bergambar ini dapat memfasilitasi keterampilan saintifik sesuai amanat kurikulum 2013

LKA dengan latar cerita bergambar ini praktis, alat dan bahan yang digunakan dalam percobaannya pun berasal dari bahan bekas dan mudah didapat. LKA dengan latar cerita bergambar ini memberi pengalaman langsung dalam proses pembelajaran bagi anak. Konsep LKA dengan cerita bergambar ini dapat di modifikasi dengan tema/konten-konten pembelajaran lain yang relevan

\section{DAFTAR PUSTAKA}

Abidin, Y. (UPI K. C. (2013). Strategi Mendongeng Kreatif, Cerdas, dan Edutaimen. Jurnal Pendidikan Anak Usia Dini, 1, 68-70. https://doi.org/doi.org/10.17509/cd.v4i1

Amali, K., Kurniawati, Y., \& Zulhiddah, Z. (2019). Pengembangan Lembar Kerja Peserta Didik Berbasis Sains Teknologi Masyarakat Pada Mata Pelajaran IPA di Sekolah Dasar. Journal of Natural Science and Integration, 2(2), https://doi.org/10.24014/jnsi.v2i2.8151

Cahaya, i made elia, \& Poerwati, C. E. (2017). Efektivitas mendongeng dalam meningkatkan kemampuan matematika anak usia dini. Media Edukasi: Jurnal Ilmu Pendidikan, 1(2), 65-73.

Depdiknas. (2008). Panduan Pengembangan Bahan Ajar. Departemen Pendidikan dan Kebudayaan.

Dores, O. J., \& Setiawan, B. (2018). Pengembangan LKS Berbasis Dongeng untuk Meningkatkan Literasi Matematis Siswa Sekolah Dasar Se- 
Kota Sintang. JPMI (Jurnal Pendidikan Matematika Indonesia), 3(2), 62. https://doi.org/10.26737/jpmi.v3i2.695

Hafidz, I. P., Ilhami, B. S., Khaironi, M., Studi, P., Guru, P., Anak, P., \& Dini, U. (2018). Implementasi Pendekatan Saintifik dalam Pembelajaran Kelompok Terhadap Perkembangan Sosial Anak. Pelita PAUD, 3(1), 36-44. https://doi.org/doi.org/10.33222/pelitapaud.v $3 \mathrm{i} 1.434$

Hariyanti. (2019). Meningkatkan Kemampuan Bahasa Ekspresif Anak Melalui Metode Bercerita Menggunakan Media Boneka Jari. Pelita PAUD, 3(2), 106-120. https://doi.org/https://doi.org/10.33222/pelita paud.v3i2.520

Juniarti, Y. (2017). Penerapan Metode Eksperimen Dalam Meningkatkan Aktivitas dan Hasil Belajar Sains Anak. Pelita PAUD, 1(2), 73 84.

https://doi.org/https://doi.org/10.33222/pelita paud.v1i2.202

Permendikbud No 146 Tahun 2014, 837 (2014). http://paud.kemdikbud.go.id/wpcontent/uploads/2016/04/Permendikbud146-Tahun-2014.pdf

Lidinillah, D. A. M. (2012). Educational Design Research: a Theoretical Framework for Action Oleh : Dindin Abdul Muiz Lidinillah. Unversitas Pendidikan Indonesia Kampus Tasikmalaya.

Nugraha, A., Ritayanti, U., Sintayani, Y., \& Maryati, S. (2015). Pedoman Pengelolaan Pembelajaran Pendidikan Anak Usia Dini (E. Yulaelawati, E. Suminah, \& K. Restuningsih (eds.)). Direktorat Pembinaan PAUD.
Nurhidayah, I., \& Wangid, M. N. (2020). Pengembangan Bahan Ajar Buku Dongeng Berbasis Sainsmatika untuk Meningkatkan Pemahaman Konsep. Aksioma: Jurnal Program Studi Pendidikan Matematika, 9(2), 259-268.

https://doi.org/https://doi.org/10.24127/ajpm. v9i2.2688

Pujiaswati, R., Mulyana, E. H., \& Mulyadi, S. (2020). Pengembangan Lembar Kerja Anak (LKA) Model STEM pada Konsep Terapung Melayang Tenggelam untuk Memfasilitasi Keterampilan Saintifik Anak Usia Dini. Agapedia, 4(1), 107-117.

Rahayuningsih, D. I., Mustaji, \& Subroto, W. T. (2019). Saintifik Untuk Meningkatkan Hasil Belajar Mata Pelajaran Ips Bagi Siswa Kelas IV Sekolah Dasar. Jurnal Review Pendidikan Dasar, 4(2).

Ratnasari, E. M., \& Zubaidah, E. (2019). Pengaruh Penggunaan Buku Cerita Bergambar Terhadap Kemampuan Berbicara Anak. Scholaria: Jurnal Pendidikan Dan Kebudayaan, 9(3), 267-275. https://doi.org/10.24246/j.js.2019.v9.i3.p267 $-275$

Susdarwati, \& Agustina, D. A. (2018). Peningkatan Keterampulan Proses Sains Flora Anak Usia Dini Melalui Pembelajaran Berbasis Alam. Pelita PAUD, 2(2), 150-165. https://doi.org/https://doi.org/10.33222/pelita paud.v2i2.229 